Article

\title{
Greenhouse and Nursery Water Management Characterization and Research Priorities in the USA
}

\author{
Sarah A. White ${ }^{1, *(\mathbb{D}}$, James S. Owen ${ }^{2}{ }^{(\mathbb{D}}$, John C. Majsztrik ${ }^{1}\left(\mathbb{D}\right.$, Lorence R. Oki $^{3}{ }^{(1)}$, \\ Paul R. Fisher ${ }^{4}$, Charles R. Hall ${ }^{5}$, John D. Lea-Cox ${ }^{6}$ and R. Thomas Fernandez ${ }^{7}$ (D) \\ 1 Department of Plant and Environmental Sciences, Clemson University, E-143 P\&AS, Clemson, SC 29634, \\ USA; jmajszt@clemson.edu \\ 2 School of Plant and Environmental Sciences, Hampton Roads Agricultural Research and Extension Center, \\ 1444 Diamond Springs Road, Virginia Beach, VA 23455, USA; jsowen@vt.edu \\ 3 Department of Plant Sciences, MS6, University of California, One Shields Avenue, Davis, CA 95616-8780, \\ USA; lroki@ucdavis.edu \\ 4 Environmental Horticulture Dept., University of Florida, 1533 Fifield Hall, P.O. Box 110670, Gainesville, \\ FL 32607, USA; pfisher@ufl.edu \\ 5 Department of Horticultural Sciences, Texas A\&M University, 2133 TAMU, HFSB Room 202, College Station, \\ TX 77843-2133, USA; c-hall@tamu.edu \\ 6 Department of Plant Science and Landscape Architecture, 2120 Plant Sciences Building, \\ University of Maryland, College Park, MD 20742-4452, USA; jlc@umd.edu \\ 7 Department of Horticulture, Michigan State University A288 Plant and Soil Science Building, East Lansing, \\ MI 48824-1325, USA; fernan15@msu.edu \\ * Correspondence: swhite4@clemson.edu; Tel.: +1-864-656-7433
}

Received: 2 October 2019; Accepted: 5 November 2019; Published: 8 November 2019

check for updates

\begin{abstract}
Nursery, floriculture, and propagation production accounted for 79\% (\$13.3 Billion) of 2017 ornamental specialty crop production in the United States. Access to high quality water sources is increasingly limited for irrigating these economically significant crops. Given the production, environmental, and economic issues associated with the use of water-including recycled, reclaimed, surface, and ground water-it is critical to develop sustainable runoff, containment, and remediation technologies, and to identify alternative sources of water. To better understand current practices and future water-related needs as perceived by grower stakeholders, an online survey was distributed nationally and five in-depth round table discussion sessions were conducted at the Mid-Atlantic Nursery Trade Show, Gulf States Horticultural Expo, California Grown Show, AmericanHort's Cultivate, and the Farwest Show with a total of 36 individual industry participants. A team of research and extension specialists facilitated by a Specialty Crops Research Initiative Planning Grant (NIFA Project \# 2011-51181-30633) analyzed and concisely summarized the results from the survey and the round table discussions. Research priorities related to water management identified by stakeholders revolved around six themes: (1) recycled water infrastructure and management; (2) contaminants; (3) plant health and water quality; (4) water treatment technologies; (5) competing and complementary water uses; (6) societal perception of agricultural water use.
\end{abstract}

Keywords: irrigation return flow; recycle; runoff; survey; round table discussion; field; container; water quality; water quantity; barriers to adoption; reclaimed water

\section{Introduction}

Floriculture (\$6.19 Billion), nursery (\$5.91 B) and propagation (\$1.19 B) sales were significant contributors to the USA economy in 2017 [1]. More than 17,000 producers (farms) grow floriculture and bedding crops, over 4300 producers grow nursery crops, and over 2000 producers grow propagative 
materials [1]. Nearly $80,000,000 \mathrm{~m}^{2}$ of greenhouse space and 20,000 ha open-air production are used to produce floriculture crops [1]. Nursery crops are produced mainly in open-air production space $(136,000 \mathrm{ha})$, with only a small portion being protected $\left(\sim 28,700,000 \mathrm{~m}^{2}\right)$ [1]. These crops require frequent irrigation, fertilizer, and pesticide applications to maintain optimal crop growth and quality. As a result, production irrigation return flow may contain agrichemicals [2,3] and pathogens $[4,5]$ that negatively impact water reuse or contaminate surrounding waters. Developing sustainable irrigation water management, containment, and remediation technologies are key factors in reducing the impact of irrigation return flow water on local ecosystems and enhancing ornamental producer use of alternative water resources [2,6-9]. Emerging legislative constraints on water use and quality signify that the ornamental industry needs to identify strategies and technologies to use and manage alternative water sources without impacting production schedules and sacrificing crop quality [10].

Water containment and reuse is a critical knowledge area due to our incomplete understanding of how to resolve many of the major issues that currently limit industry-wide implementation of irrigation return flow recycling for irrigation purposes. The goal of this study was to (1) conduct comprehensive grower surveys regarding water use and identify barriers to adopting recycling technology, (2) conduct discussion sessions to gain an understanding of industry-wide perspectives on the future of water and its management, and (3) identify research priorities using stakeholder input from listening sessions and survey results. Understanding these priorities can help guide impactful research in the future.

\section{Methods}

To better understand current practices and future water-related needs as perceived by grower stakeholders, research and extension specialists from seven Universities in the USA (Clemson University, Michigan State University, Texas A\&M University, University of California-Davis, University of Florida, University of Maryland, and Virginia Tech) submitted and were awarded a National Institute of Food Agriculture-United States Department of Agriculture, Specialty Crops Research Initiative planning grant "Containment, Remediation, and Recycling of Irrigation Water for Sustainable Ornamental Crop Production" (2011-51181-30633).

\subsection{Survey Question Development and Administration}

The goal of the survey (Understanding Ornamental Irrigation and Runoff Management Practices Nationwide and the Utility of Irrigation Sensor Networks) was to gain a better understanding of industry-wide irrigation, runoff management, and fertilization practices across the USA. This survey was reviewed and approved by the University of Maryland Institution Review Board procedures for research involving human subjects (11-0725). A subset of survey questions and responses, complementary to information gathered during the round table discussion, are included in this paper to ensure data presented herein represent a greater subset of the population of nursery and greenhouse plant growers across the USA. The questions selected are detailed in Appendix A.

The survey collected anonymous information related to the production practices of wholesale and retail greenhouse, container, and field nurseries in the USA. Participants were recruited using two strategies; email and direct contact at trade shows. Extension specialists in each state were contacted and asked to send an email to their grower list-serves and trade associations, requesting grower participation in the survey. We requested assistance from state extension specialists as we wanted to maintain the confidentiality of growers who participated, and growers are more likely to respond to requests from individuals with whom they more frequently interact.

Growers were asked to participate in the anonymous survey at five trade shows throughout the USA (see next section for complete details on timing and geographic location). Potential respondents were approached to determine if they grew plants for retail or wholesale markets. If they answered yes, they were asked to fill out the anonymous survey and were provided a business card with information on how to access the survey. The survey was open to collect responses from January 2012 through November 2012. We collected 174 responses, and this number of collected responses was similar to 
response rates for surveys conducted by other researchers collecting information from nursery and greenhouse industry participants $[11,12]$. Despite the low response rate $(4 \%$ of nursery operations in the USA), the demographics of the individuals or operations who responded were representative of the industry. Responses were collected from firms across the USA, with the size of operation ranging from small ( 0.4 to $1.6 \mathrm{ha}$ ), to medium (2.0 to $7.7 \mathrm{ha}$ ) and large (8.0 or more ha of production).

\subsection{Round Table Question Development and Discussion Sessions}

The round table discussion questions (Appendix B) were developed and refined by the research and extension specialists collaborating on the planning grant. The final questions were reviewed and approved by the Clemson University Institution Review Board procedures for research involving human subjects (2011-399). A qualitative research approach was used to develop and refine questions asked during each discussion session. The series of questions were developed to enable information gathering, initially assessing current state of knowledge of greenhouse and nursery growers related to water use, management, and regulations, with the final question related to research priorities. The sequential, building question order limited conditioned responses and did not prime participants with information that could have prejudiced responses. Interview questions were open-ended promoting and permitting open sharing, a robust discussion, and peer-learning among grower participants.

Data were collected regionally and collated so that national inferences on research priorities could be assessed. A total of 36 industry stakeholders participated. Industry participants had either committed $(n=30)$ to participating in the round table discussion sessions as part of their support of the Specialty Crops Research Initiative planning grant or were recruited by other growers to participate in the discussions $(n=6)$. Growers identified via the planning grant were recruited by nursery extension specialists within their states based on operation size (small to large) and reputation (respected) within the industry. Growers collaborating on the planning grant were contacted individually via email or phone, two weeks prior to the round table discussions and provided with a copy of the discussion questions. The round table discussion sessions were conducted at five nursery and greenhouse trade shows held in the USA in 2012: the Mid-Atlantic Nursery Trade Show (Baltimore, MD, USA); the Gulf States Horticultural Expo (Mobile, AL, USA) in January, the California Grown Show (Long Beach, CA, USA) in June; American Hort's Cultivate'12 (Columbus, OH, USA, formerly the OFA Short Course) in July; and the Farwest Show (Portland, OR, USA) in August. After obtaining grower permission to record the round table discussion session at each location, an audio recording was made and responses from each round table discussion were transcribed into a single document with no identifying information, to maintain grower anonymity.

Results were collated by keyword and topical themes. Frequency analyses were performed on data pooled across regions for each question. Frequency results were then ranked from most important among growers across regions (item was mentioned by growers most frequently) to least important (or perhaps only regionally significant in trend, but still of concern to growers).

\section{Survey and Round Table Findings}

\subsection{Survey Highlights}

Of the 174 respondents in the nursery and greenhouse grower survey, 63\% of respondents identified all or a portion of their operation as greenhouse (mean 3.6 ha; median 0.6 ha), container nursery including pot-in-pot (55\%; mean 17.2 ha; median 2.4 ha), field nursery (39\%; mean 71.6 ha; median $6.9 \mathrm{ha})$, or unspecified other ( $9 \%$; 18.8 mean; 0.6 median) with an average or median overall nursery or greenhouse size of production encompassing 76 or 9 ha, respectively. Mean and median gross income across operations was $\$ 3.5 \mathrm{M}$ and $\$ 0.5 \mathrm{M}$, respectively. Oversight of water and irrigation was performed primarily by the "owner" or "irrigation manager" whom received an hourly wage of $\$ 10-20$ per hour $(70 \%)$ or annual salary of $\$ 40,000$ or greater $(43 \%)$. Operations spent a mean $\$ 87.1$ thousand (median $\$ 17,510), 3 \%$ of the $\$ 2.8 \mathrm{M}$ mean total operation cost (median $\$ 0.3 \mathrm{M}$ ), on water 
purchases, labor, water treatment, maintenance, and associated energy to irrigate. The reported percentage agrees with Ingram et al. $[13,14]$ who reported that a mean $3.2 \%$ of the cost of producing a \#1 or \#3 evergreen shrub, Buxus spp. or Ilex spp., on the west or east USA coast, was used for water related activities.

Of those respondents who measured water usage (53\%), the volume of water used was commonly measured in terms of gallons (43\%) rather than precipitation (acre inch; $10 \%$ ). However, only $30 \%$ responded they use flow meters in their operation, which calls into question the accuracy of their water use estimates. Reported water usage per hectare per year of production in greenhouse, container nursery, and field nursery were 19.2 mean (median 1.5), 150.2 mean (median 9.6), and 61.3 mean (median 4.6) million liters, respectively. Source of irrigation water was reported as $45 \%$ surface water, $40 \%$ shallow well $(<30.5 \mathrm{~m})$, or $67 \%$ deep well $(>30.5 \mathrm{~m})$, with some operations using water from multiple sources. Respondents indicated their source water was regulated by a board $(29 \%)$, locality $(20 \%)$, state government $(49 \%)$, or the federal government $(6 \%)$. Water availability restricted operational expansion for $11 \%$ of respondents; however, $88 \%$ of respondents indicated well or pump capacity was the primary factor limiting water availability. Respondents stored water in reservoirs $(68 \%)$ or storage tanks $(40 \%)$. Stored water was primarily used to extend water quantity when primary extraction was limiting $(60 \%)$ or, to a lesser extent, blend water from different sources to ensure desired water quality ( $40 \%)$. Only $3 \%$ of respondents changed production practice (e.g., improving irrigation uniformity, altering irrigation cycle times) to extend their water supply by increasing water application or use efficiency. If growers needed to increase water availability, $53 \%$ of respondents indicated the cost-effective course of action would be to drill an additional well, install a containment reservoir $(35 \%)$, harvest rainwater $(21 \%)$, install storage tanks $(17 \%)$, or use municipal reclaimed water $(9 \%)$. Thirty-seven percent of respondents had invested in altering the infrastructure of their irrigation systems over the past 10 years.

Seventy-one percent of respondents indicated they did not collect irrigation return flow from their production area for reuse; while $30 \%$ of respondents indicated they reused water from onsite or municipal reclaimed sources to irrigate crops. Irrigation return flow water was treated using best management practices (BMPs) [15] such as vegetative ditches by $63 \%$ of the respondents prior to reuse. Seventy-three percent of respondents did not further treat recycled water to pathogens prior to reuse. Use of recycled water for application to greenhouse crops was limited (14\%) when compared to use of recycled water for irrigation of container or field nursery crops $(95 \%)$. Of these operations recycling water, $6 \%$ blended municipal or groundwater with recycled water. Respondents indicated they monitored water used in irrigation (42\%), from the containment reservoir (28\%), and irrigation return flows that leave the site $(10 \%)$.

Monthly or more frequent measurement of at least one water quality parameter, either onsite or using an outside laboratory, was performed by $38 \%$ of respondents $(n=34)$ who monitored water quality. Parameters measured in order of occurrence were (1) $\mathrm{pH}$; (2) electrical conductivity; (3) alkalinity; (4) mineral nutrients; (5) total suspended solids; (6) pathogens; (7) pesticides. The water quality parameters for which growers reported the greatest concern differed in ranking from the water quality parameters measured as follows: (1) $\mathrm{pH}$; (2) aquatic weeds; (3) alkalinity; (4) total suspended solids; (5) electrical conductivity or pathogens occurring inside the operation; (6) mineral nutrients, pesticides, or pathogens occurring outside the operation; (7) saltwater intrusion. Despite the importance of pathogens and impacts on plant health, only $37 \%, 29 \%$, and $21 \%$ of greenhouses, container nurseries, and field nurseries, respectively, treated irrigation water for plant pathogens before application to the crop. 


\subsection{Round Table Discussion Highlights}

\subsubsection{Major Water-Related Production Challenges}

Greenhouse and nursery growers discussed and ranked their top water related production challenges (Table 1) during each round table session. The main concern consistently identified by growers, across regions and production types, was the presence of contaminants or plant pathogen inoculum in their water source. Irrigation return flow (management, containment, reuse, and stormwater) was the second challenge, followed by water availability and overall quality.

Table 1. Major production challenges related to water as summarized and ranked by greenhouse and nursery growers $(n=36)$ attending five round table discussion sessions across the USA.

\begin{tabular}{|c|c|c|}
\hline Challenge Identified & Frequency & Importance \\
\hline Contaminants & 32 & 1 \\
\hline Pathogen & 11 & \\
\hline Pesticide & 7 & \\
\hline Salt accumulation & 5 & \\
\hline Nutrients & 4 & \\
\hline Weed & 3 & \\
\hline Iron & 1 & \\
\hline Algae & 1 & \\
\hline Irrigation return flow & 18 & 2 \\
\hline Management & 6 & \\
\hline Containment & 5 & \\
\hline Reuse & 4 & \\
\hline Stormwater & 3 & \\
\hline Availability & 15 & 3 \\
\hline Down the Road & 9 & \\
\hline Volume in surface water sources & 4 & \\
\hline Future regulations (availability) & 2 & \\
\hline Water quality & 7 & 4 \\
\hline General & 4 & \\
\hline $\mathrm{pH}$ & 3 & \\
\hline Efficient distribution & 5 & 5 \\
\hline Sediment control measures & 5 & 6 \\
\hline Cost of water & 4 & 6 \\
\hline Documenting volume used & 3 & 7 \\
\hline Recycled water treatment & 3 & 7 \\
\hline Groundwater issues & 1 & 8 \\
\hline
\end{tabular}

\subsubsection{Concerns for the Future}

Growers emphasized both water quantity (availability) and uncertainty related to regulations (Table 2) when asked about concerns regarding their water supply over the next 10 years. In terms of the quantity and availability of water, growers expressed concern about regulations that impact the permitting process for new wells and whether they would be able to gain a permit to increase the maximum amount of water withdrawn from a well. When expressing concern about access to new wells, growers discussed both current and (potentially) new capacity use restrictions (by aquifer or location), depletion of the water table, and connectivity between aquifers and surface waters as reasons new permits may not be granted. Long-term drought was also mentioned in terms of the use of existing water resources or access to additional water resources if their current source was diminished or depleted. Inter-state "water wars" and demand to maintain adequate down-stream flows in surface waters, both to facilitate support of industries in states who share river resources and to maintain the ecological health of the river system [16], were reasons for concern about access to additional water when drought-induced water shortages occur. 
Table 2. Concerns related to water supply in the USA over the next 10 years, ranked by growers $(n=36)$ attending five round table discussion sessions.

\begin{tabular}{|c|c|c|}
\hline Water Supply Concerns & Frequency & Importance \\
\hline Quantity or availability & 17 & 1 \\
\hline Increase permits for water volume & 5 & \\
\hline Depletion of current water table & 2 & \\
\hline Long term drought & 8 & \\
\hline Regulation-government or environmental restrictions & 14 & 2 \\
\hline $\begin{array}{l}\text { Changes in public policy (monitoring, groundwater } \\
\text { withdrawal, permit for wells) }\end{array}$ & 4 & \\
\hline Very expensive to implement BMPs & 2 & \\
\hline Total maximum daily loads & 1 & \\
\hline New well permits & 3 & \\
\hline Quality & 10 & 3 \\
\hline Pathogen and water treatment & 1 & \\
\hline Aquifer contamination & 1 & \\
\hline Managing irrigation return flow & 1 & \\
\hline Cost (escalation in cost as more limited in supply) & 8 & 4 \\
\hline Competition & 1 & \\
\hline Water ownership & 4 & 5 \\
\hline Who owns water under property? & 1 & \\
\hline Inter-state water disputes & 2 & \\
\hline Redundancy (multiple water sources) & 1 & 6 \\
\hline
\end{tabular}

The use of municipal reclaimed water was also discussed. Access to municipal reclaimed water is increasing in many areas of the USA, particularly in coastal areas where disposal of treated urban wastewater is problematic in terms of volume to be released and proximity to salinity-sensitive ecological communities $[17,18]$. Reclaimed wastewater is also used for irrigation of agricultural crops on every continent, with varied levels of treatment prior to use [19]. Growers acknowledged their need to have access to this water resource and mentioned that their use for irrigation can or does help to dispose of reclaimed water. Irrigation-based use of reclaimed municipal wastewater may also have the added environmental benefit of reducing the presence of pharmaceutically active compounds in water [20]. The infrastructure investment needed by growers to use municipal reclaimed water is large, because it involves new piping to the irrigation system. Pipes that carry municipal reclaimed water cannot be connected to potable water sources, due to the regulatory concern regarding biological contamination [21]. Some growers noted the municipal reclaimed water was as expensive as their other water sources, and sometimes lower in quality (higher salt content).

Growers who recycle water on-site mentioned the perception of increased water consumption if one looks at data on the water volume applied to crops, rather than the volume of supplemental water consumed from freshwater sources. A grower used the example that if they used 10,600,000 L of water per hectare per year and have $55 \%$ return of water for reuse, actual draw from a surface or ground water source, without recycling, is likely to report only 4,570,000 to 6,096,000 $\mathrm{L}$ of water use per hectare per year. Therefore, consumptive use of freshwater is likely only $43 \%$ to $57 \%$ of the metered amount of water applied when water recycling and reuse is taken into account.

\subsubsection{Water Source Options}

When asked about alternate water sources for irrigation if their current water supply were to become limited, growers indicated they would have various responses (Table 3). Change in production strategy was the most common solution to water shortages. The practices changed included increasing irrigation efficiency (e.g., closer plant spacing, grouping plants with similar water use needs, redesign of irrigation system for efficiency, drip or micro-irrigation rather than overhead irrigation), using flood bench or flood floor irrigation so that water can be more easily recycled, and altering the substrate used to grow the crops to one with a higher water holding or buffering capacity. 
Table 3. Options for alternative water sources if irrigation supply were limited, ranked by growers $(n=36)$ attending five round table discussion sessions in the USA.

\begin{tabular}{|c|c|c|}
\hline Challenge Identified & Frequency & Rank \\
\hline Change production strategy & 14 & 1 \\
\hline Increase irrigation efficiency & 8 & \\
\hline Flood bench/flood floor irrigation & 3 & \\
\hline Change substrate to heavier mix & 2 & \\
\hline Increase storage & 10 & 2 \\
\hline Rainwater capture and storage & 4 & \\
\hline Irrigation return flow capture and storage & 2 & \\
\hline Reclaimed water & 7 & 3 \\
\hline Recycle reservoir & 5 & 4 \\
\hline City water & 4 & 5 \\
\hline Groundwater (wells) & 3 & 6 \\
\hline Surface water & 3 & 6 \\
\hline No alternative source & 3 & 6 \\
\hline Not an issue & 2 & 7 \\
\hline Blend well and recycled & 1 & 8 \\
\hline
\end{tabular}

The second most common option was to increase on-farm water storage capacity, both for collection of production irrigation return flow and stormwater. Finally, growers would evaluate potential for using municipal reclaimed water or recycling runoff water. When evaluating municipal reclaimed water, the cost of infrastructure necessary to integrate this water source with their production system was the greatest barrier, but concerns were also expressed with regard to the quality of municipal reclaimed water. Parsons et al. [22] noted that growers use municipal reclaimed water extensively in $\mathrm{FL}$, and in CA reclaimed water is a necessary source of water for irrigation. When evaluating whether to initiate water recycling, growers also mentioned costs and the need for additional information about (1) differential losses, or how much of water applied during irrigation events actually returns to the recycling reservoir; (2) potential for plant pathogen contamination of recycled water; (3) efficacy of treatment options; (4) return on investment [23]. Recently, Pitton et al. [24] published a cost analysis study of installing water recycling infrastructure at a plant nursery that should help address grower concerns over return on investment, at least in regions of the USA where water is costly (more than $\$ 0.60$ per $1000 \mathrm{~L}$ ). The other water source options mentioned were municipal water, drilling more wells, and withdrawals from surface waters. Some growers mentioned that access to adequate water resources were not a problem for their location. Growers also perceived that if they are too proactive in investing in water saving technologies, that when water shortages occur, they may not get credit for already being water-efficient.

\subsubsection{Regulatory Issues and Production Practices}

Regulatory concerns included the costs of compliance, impact of irrigation return flow on impaired waterways [25], and competition with off-shore growers. Competition from international growers was a concern because growers in the USA will likely have to deal with increasingly stringent environmentally-based water regulations, whereas environmental regulations for growers in other countries (likely to export plant material to the USA) may not be as stringent. Therefore, compliance costs may be lower outside the USA and result in a competitive advantage [26]. Hall et al. [27] noted that grower perception of the stringency of environmental regulations in states within the USA, did not impact adoption of BMPs to meet environmental regulations, growers in "less strict" states were as likely to adopt BMPs as those in "strict" states. Floriculture growers were proactive in implementing environmentally sustainable practices, regardless of the regulations in place in their state [27].

When asked if growers would change production practices in response to (potential) regulations grower responses varied. These responses included (1) no action would be taken because they were not sure which technologies to manage irrigation return flow were most effective; (2) little to no water 
leaves the property at present, or irrigation return flow that leaves the property is already treated, so no change in practice is necessary; or (3) nutrient and water management plans would be put in place that are approved by their respective state department of agriculture. Growers also noted the need to define the specific costs and technical requirements for implementing a BMP, the need to document successful implementation, and to calculate the impact of the BMP on changes in water quality, whether that is measured in terms of changes in concentration or reduction in contaminant load. In terms of managing irrigation return flow water quality one grower said, "We've done the best we can already. I care about what's going on with that water. I realize that chemicals are in the water leaving my property... I think I need help. I could do a better job if I knew more about what I could do to improve that runoff." This is a clear statement that additional science-based information resources are needed both about the various contaminants that impact growers, but also about the efficacy of treatment technologies and BMPs that are available to help manage those contaminants.

Other conversations regarding regulatory issues revolved around two themes. The first was that even in some states where minimal regulations exist requiring irrigation return flow management or treatment, the costs associated with inefficient use of fertilizers and pesticides can be high and provide an economic incentive to minimize losses of these agrichemicals via more efficient water use. The second theme was that of frustration over conflicting jurisdictions and guidelines within and among intra- and inter-state agencies, and the need for better communication and consistency in requirements across agencies.

\subsubsection{Feasibility of Alternative Water Resource Use}

When growers were asked about the information needed to consider using an alternative water source for irrigation, there were several consistent themes related to availability, cost, treatment efficacy, and quality (Table 4). In terms of availability, most growers wanted additional information about long-term availability and the consistency of both the volume (year-round availability or minimum volume required to be used) and the quality of the water. The quality of water available from municipal reclaimed water varies from source to source, with some maintaining consistent quality outputs [22], and others more variable [28]. The contaminants of concern present, whether chemical or biological, could be detrimental to human health, plant health, or consumer acceptance of the final product [22,29-32]. Changing water quality could be detrimental to crop growth, especially if the load of contaminants present is inconsistent over time [30].

Cost was the second most requested information component needed to consider using an alternative water source for irrigation. Information is needed on the cost per unit volume used as well as infrastructure investment costs, because one has to install new pipes, and potentially change how water is applied to crops (overhead irrigation to drip-irrigation) to comply with the human health regulations associated with reclaimed water use. If water quality was variable, growers wanted information on how they needed to treat the water to make it consistently useable. Pathogen presence was the only contaminant identified specifically as an information need, but the growers did not differentiate between human or plant pathogens, so it is unclear for which pathogen growers needed additional information. Dery et al. [31] reported that information on the quality of the alternative water source shifted grower willingness to consider using a non-traditional water source by $16 \%$.

Of the factors identified by growers that limited operational capacity to use an alternative water source for irrigation, availability and geographic limitations were most commonly identified, followed by regulations on how to use the water, potential for crop sensitivity to pathogens, cost of infrastructure modifications, and concerns over community and consumer perception about how the water will impact their health (Table 5). Community and consumer concerns have been identified by other researchers evaluating reclaimed water use, with particular focus on both grower and public acceptance of crops grown using reclaimed wastewater [31,33]. Dery et al. [31] reported that even though the majority of growers (68\%) were concerned about water availability, only $48 \%$ of their respondents had thought about using a non-traditional water source for irrigation. Savchencko et al. [33] surveyed 
consumers in the mid-Atlantic region of the USA and reported that those consumers who had heard about reclaimed water were more likely to accept its use, but overall consumers were reluctant to use or buy products produced using reclaimed water. This finding is a significant barrier to agricultural use of reclaimed wastewater, unless its use is paired with educational messaging at the consumer level to help overcome stigmas associated with crops produced using non-traditional water sources.

Table 4. Information needed to consider using alternative water sources for irrigation, ranked by growers $(n=36)$ attending five round table discussion sessions in the USA.

\begin{tabular}{|c|c|c|}
\hline Challenge Identified & Frequency & Rank \\
\hline Availability & 13 & 1 \\
\hline Present-day consistency & 8 & \\
\hline Long-term consistency of supply & 5 & \\
\hline Cost & 10 & 2 \\
\hline Purchase & 3 & \\
\hline Install & 2 & \\
\hline Maintenance & 1 & \\
\hline Do we have to filter? & 2 & \\
\hline Do we have to purify? & 2 & \\
\hline Treatment efficacy & 10 & 2 \\
\hline General efficacy & 6 & \\
\hline Pathogens & 3 & \\
\hline Maintain water quality & 1 & \\
\hline Long-term quality & 8 & 3 \\
\hline Reclaimed water quality & 8 & 3 \\
\hline Quality & 3 & \\
\hline High nutrient/salt levels & 2 & \\
\hline Consistency & 2 & \\
\hline Chemistry & 1 & \\
\hline Capture rainwater & 3 & 4 \\
\hline Volume needed & 2 & \\
\hline Pesticides on suspended sediments & 1 & \\
\hline Alternative water source-geography limited & 3 & 4 \\
\hline Municipal water-how, when, cost & 2 & 5 \\
\hline Better water than current & 2 & 5 \\
\hline Water usage rates (conservation strategies) & 1 & 6 \\
\hline
\end{tabular}

Table 5. Factors limiting your operation's capacity to use alternative water sources for irrigation, ranked by growers $(n=36)$ attending five round table discussion sessions in the USA.

\begin{tabular}{ccc}
\hline Challenge Identified & Frequency & Rank \\
\hline Availability/logistics & 7 & 1 \\
Options for alternative water sources limited by geographic location & 5 & 2 \\
(land availability) & 4 & 3 \\
Regulations & 3 & 4 \\
Crop sensitive to specific pathogens & 3 & 4 \\
Infrastructure costs & 2 & 5 \\
Community perception/concern, what happens after you apply (health concerns) & 1 & 6 \\
Crop sensitivity to salts-need pure, clean mist water & & \\
\hline
\end{tabular}

\subsubsection{Technology Adoption: When, Why, and How}

When growers were asked "How do economic factors influence your willingness to adopt a technology?" and "When do you decide you are willing to adopt a technology?", answers focused on economic and practical considerations (Table 6). Growers were more likely to adopt a technology if they knew it was reliable; likely to still be around in 10 years. When that duration declined to 5-7 years, fewer growers were willing to be early adopters, preferring to let others be innovators and 
early adopters [34]. The money saved by adopting the technology must meet or exceed the ongoing cost of maintenance. If the return on investment (ROI) was less than 3 years, some growers indicated they were likely to adopt the technology, and if ROI was less than 2 years, no barrier was perceived, and the decision was a "no-brainer". Other factors began to influence whether or not adoption was likely to occur if ROI resulting from the adoption of a technology took longer than 5 years. Growers indicated potential for adoption even if ROI took as long as 10 years if the technology being considered was likely to address an environmental compliance or regulatory issue. Other growers indicated adoption depends on more than just the initial cost and ROI, including the ease of use and simplicity of maintenance. If maintenance was difficult or the technology was not simple to operate, growers were unlikely to use the technology, even if it might save money over the long-term. Lamm et al. [35] surveyed 24 nursery and greenhouse operators in the USA and reported that barriers to adoption included similar factors including compatibility with currently used systems, high cost of replacing systems, and the perception that new technologies "do not fit in with the traditional hands-on approach to horticulture."

Table 6. Growers $(n=36)$ attending five round table discussion sessions were asked to discuss how economic and practical considerations influence adoption of new technologies in the USA.

\begin{tabular}{ccc}
\hline Factors Influencing Adoption of Technology & Frequency & Rank \\
\hline Economic & & \\
\hline Reliability (life-span) of technology & 10 & 1 \\
Initial cost & 5 & 2 \\
Return on investment & 5 & \\
Cost/simplicity of maintenance of technology & 4 & 3 \\
Availability of financing & 2 & 4 \\
\hline Practical & & \\
\hline System simplicity and usability & 5 & \\
Cost & 5 & 2 \\
Longevity of system (reliability) & 3 & \\
Plant quality & 3 & 3 \\
Ease of maintenance & 3 & \\
Consistent pathogen control & 2 & \\
Safety & 2 & \\
Efficiency & 2 & \\
Adaptability to specific site & 2 & \\
\hline
\end{tabular}

When considering practical factors, similar trends in conversation were evident; focused on reliability, maintenance, and cost. System simplicity and usability were key, growers stated that the individuals using (and sometimes installing) treatment technologies are often "very simple people," indicating they are untrained or uneducated in water treatment. Growers prefer that new technologies are designed so that they can be understood and maintained without specialized training or advanced degrees. The second most common practical factors that influenced technology adoption were impacts of the treatment technology on plant health (same or improved plant quality a requirement) and consistency to control pathogens (i.e., Does the technology consistently do what it is supposed to do without compromising plant quality?). Adaptability of the technology was also important, because ease of integration within current production sites or practices was also a critical factor in the decision-making process.

\subsubsection{Recycling Irrigation Return Flow: The Pros and Cons}

Growers were asked a series of questions regarding if they recycled irrigation return flow or stormwater. These questions (Appendix B, questions 11-13) focused on understanding "why" or "why 
not" water was recycled, information needed by growers to help design the water conveyance and management systems, knowledge gaps, and lessons learned.

When those who recycle water were asked "How much irrigation return flow do you capture from rainfall and production?" responses ranged from $50 \%$ to $100 \%$. Some growers began to discuss how they designed their recycling system (e.g., a two-pond system with a "dirty" reservoir and a "clean" reservoir) and their lack of concern over buildup of contaminants in recycled water because dilution (stormwater) was helping keep contaminants concentrations low, thus not impacting plant quality. When asked about infrastructure, growers indicated they consulted with engineers, the Natural Resource Conservation Service (USDA-NRCS), or both to help design drainage systems (e.g., tile drains, pipes, ditches) and reservoirs.

When asked why they capture and recycle irrigation return flow or stormwater runoff answers ranged from redundancy and capacity $(n=8)$, cost savings $(n=5)$, and stewardship $(n=3)$ to current $(n=3)$ and potential $(n=3)$ regulations. Other reasons brought up in further discussions generally centered around economics including (1) recycling nutrients from fertilizers leached in irrigation return flow-reducing the rates at which water soluble fertilizers need to be injected for plant growth (resource and cost savings); (2) surface water is cheaper to pump than ground water (costs and energy savings); or (3) having storage capacity beyond their daily needs using surface waters was a cheaper risk management system than investing in extra pumps and wells in a groundwater system.

When growers were asked what information would help them more efficiently manage water, grower responses varied widely and included information about water quality (water treatment options, disease potential from recycled water, salt accumulation, $\mathrm{pH}$ variability), consumptive use (evapotranspiration and coefficients of evaporation), and sizing of reservoirs. Infrastructure design information needed by growers was related to reservoir sizing for adequate storage of both stormwater and irrigation return flow, how to line a reservoir (cement or plastic membrane), and whether it was necessary to aerate their reservoir.

Growers then discussed information gaps that would have helped them design their water capturing and recycling system. The first information gap was related to how much water the nursery actually uses. Many nursery growers across the USA do not know how much water they apply on a daily basis. The second gap was on how to size a reservoir based on production watershed draining into a reservoir and expected return flow. Another consideration was reservoir sizing based on magnitude of storm events: Should capacity to capture and store water be based on a 50-year ( $24 \mathrm{~h}$ ) storm event? What happens if there is a 100-year storm event? Will my infrastructure get washed away?

When asked to give advice to growers and operations considering investing in recycling infrastructure, many suggestions were made and included research your current or proposed site, give yourself options, understand the system (maintenance, operation costs, and life expectancy of the system), delineate wetlands, design with sediment management in mind, monitor water quality, and know how much water you use and document your water use so you know how much you need. One of the most striking comments from this section of dialogue was this: "Most importantly, recycle your contained water. You will not make a more important decision if you are in the horticulture industry because without water there is no horticulture."

Reasons given for why growers did not currently capture and recycle irrigation return flow by growers who do not recycle included elevation and grades were not adequate to move capture water, proximity of ground water to the land surface (high water table), need for good quality water to grow some sensitive crops, return on investment does not justify the expense, and there was no or little irrigation return flow from production beds (beds have a high percolation rate). When asked what information they needed to help implement recycling in the future, growers mentioned knowing water usage and irrigation return flow rates, volume of water to collect, land footprint required (what land might be taken out of production to install recycling infrastructure), how to design BMPs to filter water before it enters reservoirs, and water quality concerns. 


\subsubsection{Contaminants, Water Recycling, and Treatment Technologies}

Growers were asked to list the contaminants that concerned them when considering recycling irrigation return flow (Table 7). Four major questions were raised by growers about recycling and reusing water.

(1) Is the presence of pathogens an issue?

(2) Do salts accumulate?

(3) Do pesticides accumulate?

(4) What are the most effective and economical treatment options?

When data were collated, the highest priority contaminant potentially present in recycled irrigation water was pesticide residues (herbicides and plant growth regulators), followed closely by plant pathogens, fertilizer salts, and weed seeds.

Table 7. The contaminants of most concern when considering recycling irrigation return flow determined by growers $(n=36)$ attending five round table discussion sessions in the USA.

\begin{tabular}{ccc}
\hline Contaminants & Frequency & Rank \\
\hline Pesticides (herbicides, plant growth regulators) & 12 & 1 \\
Plant pathogens & 9 & 2 \\
Nitrates, phosphates, salts & 5 & 3 \\
Weed Seeds & 5 & \\
Algae & 3 & 4 \\
Duckweed & 2 & 5 \\
Atmospheric pollutants & 1 & 6 \\
Suspended solids & 1 & \\
pH (diurnal cycling) & 1 & \\
\hline
\end{tabular}

Many treatment technologies have been vetted in scientific literature that could be employed by growers to manage these contaminants in recycled irrigation water. Treatment technologies most commonly employed by nursery and greenhouse growers included filtration [2], vegetative buffers [36,37], retention reservoirs [38], constructed wetlands [39,40], and floating wetlands [41,42]. However, grower questions persist related to treatment technologies sizing, management and maintenance, efficacy, and ease of use. The need to fill gaps in information regarding implementation of treatment technologies becomes more important as design complexity increases.

\section{Research Priorities}

Growers discussed critical research needs related to containment, remediation, and recycling of irrigation water-focusing on enhancing their operation's economic and environmental sustainability and decision-making needs for (1) recycled water infrastructure and management; (2) contaminants; (3) plant health and water quality; (4) water treatment technologies; (5) competing and complementary water uses; (6) societal perception of agricultural water use. Specific questions raised include:

\subsection{Recycled Water Infrastructure and Management}

- Is there an optimum water recycling method?

- $\quad$ Best practices to manage recycled water

Liner for reservoir?

Clean water before it enters the reservoir?

- Are there other water storage technologies (e.g., large, subterranean cisterns) for field production? 


\subsection{Contaminants}

- Is there an easy (and accurate) test for the presence of plant pathogens, salts, and chemicals?

- How necessary is it to control plant pathogens?

- Do pesticide residues accumulate?

- Does $\mathrm{pH}$ shift in water influence plant quality?

\subsection{Plant Health and Water Quality}

- How does water quality relate to plant health?

- Is there a list of plants to grow using water of differing quality?

- Can we refine management practices based on water quality, water application method, soil mixes, return rates, and environmental factors?

\subsection{Water Treatment Technologies}

- Which treatments most effectively control plant pathogens?

- Is it economically feasible to invest in treatment systems? Do the benefits of the treatment system outweigh the costs associated with installation and on-going maintenance?

- What plants should be used in vegetative channels and waterways? Does plant selection change with the contaminant(s) present (e.g., plant pathogens, pesticides, or sediment)?

- Are there treatment systems that can be dual duty-water treatment while growing a second marketable crop?

- Is there cost-effective desalination?

\subsection{Competing and Complementary Water Uses}

- Can we integrate nursery water research with other industries with related issues (e.g., biofuels and sources of biofuels (algae) can nurseries use recycling reservoirs to produce algal crops)?

- Are there places that need nutrient rich water where it could be "traded"?

- What water quality is "good enough" to grow crops? Is there an industry we can partner with to use their effluent for irrigation, further treating it while growing our crops?

\subsection{Societal Perception of Agricultural Water Use}

- Are there water quality benchmarks for container growers that can help keep them in compliance with regulations?

- Is there information on the fate and mobility of the most common chemicals used by the industry? Desire expressed for a listing of common chemicals used and explanation about compound chemistry and potential to cause environmental problems—will it leach, sorb to soil, contaminate ground water?

- How can we educate consumers, legislators, and policymakers about our production practices and conservation efforts-to better alleviate their concerns about environmental safety and stewardship?

\section{Conclusions}

Overall, many pertinent issues and concerns were raised in both the survey and listening sessions with greenhouse and nursery growers in the USA. Priority grower information needs that extension education programs should address relate to (1) water management practices; (2) alternative water sources and backup water supplies; (3) measuring water use, whether water is recycled or single use; (4) estimation of production return flow volume; (5) water treatment infrastructure design. Grower identified research priorities were classified into six thematic areas: (1) recycled water infrastructure and management; (2) contaminants; (3) plant health and water quality; (4) water treatment technologies; 
(5) competing and complementary water uses; and (6) societal perception of agricultural water use. These research areas can be used to inform research and extension communities, guiding development of future research plans and education programs responsive to grower priorities. Addressing these water-research issues is important for the long-term economic sustainability of specialty crop growers in the USA. Many of the findings from future research will likely be applicable not just to greenhouse and nursery growers, but also to other agricultural producers and commodities.

Author Contributions: S.A.W., J.S.O., J.C.M., L.R.O., P.R.F., C.R.H., J.D.L.-C. and R.T.F. conceived, designed, and conducted one or more of the surveys and round table discussion and revised the manuscript; S.A.W. and J.C.M. analyzed the results; S.A.W. and J.S.O. wrote the manuscript.

Funding: This research was funded by the National Institute of Food and Agriculture, U.S. Department of Agriculture, under grant numbers Award \#2011-51181-30633 and \#2014- 51181-22372. This material is based upon work supported by the NIFA-USDA, under project number SC-1700536 \& SC-1700539.

Acknowledgments: Technical Contribution No. 6802 of the Clemson University Experiment Station.

Conflicts of Interest: The authors declare no conflict of interest. The funding sponsors had no role in the design of the study; in the collection, analyses, or interpretation of data; in the writing of the manuscript, and in the decision to publish the results.

\section{Appendix A}

Survey questions selected for inclusion in Appendix A were those related demographics and water management practices. Survey questions not included in Appendix A were related to wireless sensor networks and integrated pest management. Questions were answered by nursery and greenhouse growers. The total number of respondents to the survey were 174. Respondents were permitted to skip questions. The questions are listed by their question number in the survey and the number of respondents to each question are noted in parenthesis following each question. References in the text to percentage of respondents answering questions refer to the number that answered a particular question.

2. Which operation types are currently used for growing ornamental plants at your operation? Please check all that apply: (A) Greenhouse; (B) Container Nursery; (C) Field Nursery; (D) None of the above. $(n=152)$.

3. What is the total size of your operation in acres? Include all land used for ornamental plants, agriculture, structures etc. If you have more than one location, add all locations together. $(n=107)$.

4. Please fill in the information below for the agricultural production portion of your operation only. If possible, do not include area taken up by roads, buildings, buffers etc. How many acres do you have at your operation for each production type? $(n=107)$.

18. Who is responsible for applying irrigation at your operation? This is the person who actually turns irrigation valves, sets the timer, irrigates by hand etc. Please check all that apply: (A) Owner; (B) Individual manager; (C) Individuals other than irrigation manager; (D) Other (please specify). $(n=77)$.

19. We would like to know the wage of the person responsible for irrigation management at your operation. If there is more than one person responsible for irrigation management, please fill out the information below for the person earning the highest wage. You can answer either the hourly wage, or yearly wage of the person responsible for irrigation management, whichever is easier. Please select your preferred method for the person's approximate wage. $(n=78)$.

$20 / 21$. What is the before tax wage of the person responsible for irrigation management at your operation? This is the person who makes decisions about which plants get watered during the course of the day. (20) Hourly: (A) Up to $\$ 10 / \mathrm{h}$; (B) $\$ 10-20 / \mathrm{h}$; (C) $\$ 20 / \mathrm{h}$ or more. $(n=32)$ (21) Wage: (A) Up to $\$ 20,000 /$ year; (B) $\$ 20,000-40,000 /$ year; (C) $\$ 40,000 /$ year or more. $(n=46)$.

22. Do you measure water volume applied in Gallons or Acre Inches for your ornamental operation? (A) Gallons; (B) Acre inches; (C) We do not measure irrigation volume. ( $n=77$ ).

23. Approximately how many gallons of water do you use per calendar year in each of the following production areas? Fill in the blank for greenhouse, container, field. $(n=26)$. 
24. Approximately how many acre inches of water do you use per calendar year in each of the following production areas? Fill in the blank for greenhouse, container, field. $(n=7)$.

25. How much does each source of water listed below contribute to the ornamental portion of your operation's irrigation? Answers should sum to 100 (A) Percent (\%) shallow well (less than 100 feet deep); (B) Percent (\%) deep well (more than 100 feet deep); (C) Percent (\%) surface (lake or river); (D) Percent (\%) recycle/retaining pond; (E) Percent (\%) rainfall collection; (F) Percent (\%) municipal water; $(\mathrm{G})$ Percent $(\%)$ reclaimed water/greywater; $(\mathrm{H})$ Percent $(\%)$ other. $(n=65)$.

27. Is your water supply regulated by any of the following outside agencies? Check all that apply: (A) Water board; (B) Local government; (C) State government; (D) Federal government; (E) Other (please specify). $(n=35)$.

30. Do you store excess water for irrigation on your operation? (A) Yes; (B) No. $(n=69)$.

31. Where do you store excess water? Check all that apply: (A) Open air pond (containment pond); (B) Tank/cistern; (C) covered plastic tank. $(n=25)$.

32. Why do you store excess water? Choose all that apply: (A) Adequate volume; (B) Adequate flow rates; (C) Adequate supply during droughts; (D) Water quality (e.g., to reduce salinity); (E) Other (please specify). $(n=25)$.

33. Some operations can expand, while other cannot expand because there is not enough additional water available. Suppose you wanted to expand your operation, would water restrictions prevent you from doing so? (A) No, water is not a restriction to expansion; (B) Yes, water restricts expansion. $(n=69)$.

38. Assuming you needed more water for your ornamental operation, which of the following would be the most cost-effective way(s) for you to extend your water supply? Check all that apply: (A) Drill an additional well; (B) Rainwater collection; (C) Storage/containment ponds; (D) Storage/pressure tanks; (E) Municipal water; (F) Reclaimed/greywater; (G) Other (please specify). $(n=66)$.

39. In the past 10 years, have you altered the infrastructure of your irrigation system? (A) No; (B) Yes. $(n=69)$.

41. Do you monitor water quality at any of the following locations? (A) Well water; (B) Surface water (not containment ponds); (C) Water in containment ponds; (D) Irrigation water at nozzle; (E) Runoff water leaving your operation; (F) Other (please specify). $(n=69)$.

44. What percentage of the total land area for your ornamental operation drains water that is collected for reuse, treated and released from your operation, or not treated? Answers should sum to $100 \%$ of ornamental land area where water is: (A) Percent (\%) captured for reuse; (B) Percent (\%) captured and treated before release; (C) Percent (\%) captured and not treated before release; (D) Percent (\%) not captured. $(n=60)$.

47. Do you use any best management practices such as vegetated ditches, sediment catch basins, containment basins etc. to remove (filter) sediment? (A) Yes; (B) No. $(n=65)$.

49. Do you test the water in your containment pond either at your operation, or at a public or private testing facility? (A) No; (B) Yes. $(n=64)$.

50. How often do you monitor recycling pond water quality using testing equipment at your operation? (A) Weekly; (B) Monthly; (C) Once a season; (D) Once a year; (E) Less than once a year. $(n=17)$.

51. How often do you monitor recycling pond water quality using testing equipment at an outside laboratory? (A) Weekly; (B) Monthly; (C) Once a season; (D) Once a year; (E) Less than once a year. $(n=17)$.

52. For the ponds that you use for recycling, which of the following impact the water quality in your recycling (containment) pond(s)? (A) Excess nutrients; (B) pH; (C) Electrical conductivity (EC); (D) Suspended solids; (E) Aquatic weeds; (F) Salt intrusion; (G) Alkalinity; (H) Pesticides from outside your operation; (I) Pesticides from within your operation; (J) Pathogens from outside your operation; (K) Pathogens from within your operation; (L) Other (please specify). $(n=16)$. 
53. For the ponds that you use for recycling, which of the following do you measure? (A) Nutrients; (B) $\mathrm{pH}$; (C) Electrical conductivity (EC); (D) Suspended solids; (E) Alkalinity; (F) Pesticides; (G) Pathogens; (H) Other (please specify). $(n=16)$.

54. Do you reuse captured irrigation return flow water for irrigation? (A) No; (B) Yes. $(n=64)$.

57. Where is captured water used for irrigation? Check all that apply: (A) Greenhouse irrigation return flow is used for greenhouse irrigation (including flood floors); (B) Greenhouse irrigation return flow is used for container or field irrigation; (C) Container or field irrigation return flow is used for container or field irrigation; (D) Greenhouse, container, or field irrigation return flow is used for other agricultural cropland. $(n=21)$.

62. What water sources are mixed in your recycling (containment) pond(s)? Check all that apply: (A) Irrigation return flow; (B) Rainfall runoff; (C) Well water; (D) Municipal water; (E) Surface water (nearby lake or stream); (F) Other (please specify). $(n=10)$.

63. Please answer the following questions (no/yes) regarding water treatment from your containment pond(s): (A) Water is used without treatment; (B) Water is treated regardless of whether pathogens are present; (C) Pathogen presence is monitored by baiting or similar practice; (D) Pathogen treatment is based on baiting results. $(n=24)$.

64. Please provide your typical gross annual income for your ornamental operation to the nearest $\$ 10,000$ (for example, $\$ 142,500$ would be reported as $\$ 140,000$ ). We are looking for your income from growing and selling ornamental plants only. Do not use commas or other punctuation in your answer. $(n=54)$.

65. What is the typical total annual cost to run the ornamental portion of the operation? Please include all labor, material, taxes, fuel etc. We are looking for your costs for growing and selling ornamental plants only. $(n=51)$.

66. Please provide the following costs for your ornamental operation during a typical calendar year. We are looking for your costs associated with growing and selling ornamental plants only. (A) Fertilizer (\$); (B) Disease management (ex: fungicides) (\$); (C) Water treatment (e.g., chlorination) (\$); (D) Pumping costs (ex. electricity, fuel) (\$); (E) Water Purchases (state, county etc.) (\$); (F) Labor for running/maintaining irrigation system (\$); (G) Cost of irrigation system maintenance (including new pumps lines, nozzles, etc.) (\$). $(n=48)$.

$74 / 103$. Do you use flow meters in your greenhouse/nursery operation? $(n=30 / 28)$.

$76 / 116$. How is irrigation controlled in the greenhouse/nursery portion of the operation? $(n=30 / 34)$.

\section{Appendix B}

Round table discussion questions posed to greenhouse and nursery growers who participated in the five discussion sessions hosted across the USA.

1. List the top container, field, and/or greenhouse production challenges related to water.

2. What concerns do you have related to your water supply over the next 10 years?

3. If your current water source were to become limited, what options for irrigation water would you investigate?

4. How do potential regulatory issues related to nutrient, sediment, and pesticides in runoff leaving your property influence your production practices (i.e., irrigation handling, fertilization rates, best management practices for irrigation return flow from production areas, etc.).

5. What information do you need to be willing to consider alternative water sources for irrigation?

6. What factors limit the capacity of your operation to use alternative water sources for irrigation?

7. How do economic factors influence your willingness to adopt a technology?

8. What type of information needs to be included in a cost-benefit analysis of the use of recycled water sources or irrigation sensor networks?

9. What other factors do you consider when considering adoption of a new technology? 
10. How do environmentally related factors influence your production practices?

11. If you capture and recycle irrigation return flow or stormwater runoff for reuse:
a. Why did you implement these practices?
b. What information would help you more efficiently manage your runoff and ponds?
c. What information did you need (related to infrastructure-conveyance, vegetated ditched,
sedimentation ponds, pond sizing, etc.) when you designed your containment/recycling system?
d. Of the information (in (c)), where did you find the biggest gaps in knowledge that would have helped you design your containment/retention pond system?
e. Please share any advice for ornamental operations considering implementing containment technology that would help them more efficiently design and manage their systems.

12. If you do not capture and recycle irrigation return flow or stormwater runoff for reuse:
a. What is (are) the major reasons you do not currently capture runoff water?
b. What factors limit your ability to recapture water?
c. If in the future, you considered capturing irrigation return flow and stormwater runoff for recycling, what information do you need to help you implement the technology?

13. What factors limit your optimal use of containment/retention ponds for irrigation water-consider what research would be most beneficial for your operation related to water handling issues?

14. List the contaminants that concern you most when you consider recycling your irrigation return flow.

15. Are you aware of the cleansing (filtration, remediation, etc.) technologies available that can improve irrigation return flow water quality? If so, please list those with which you are familiar.

a. Do you have access to information about the effectiveness/performance of these technologies?

b. Do you think there is enough information available for you to implement these technologies?

16. What research, related to containment, remediation, and recycling of irrigation water, do you think is most critical to enhance your operations economic and environmental sustainability and make the best decisions for implementing water-saving practices at your operation?

\section{References}

1. United States Department of Agriculture, NASS. 2017 Census of Agriculture: United States Summary and State Data; USDA: Washington, DC, USA, 2019; Volume 1.

2. Majsztrik, J.C.; Fernandez, R.T.; Fisher, P.R.; Hitchcock, D.R.; Lea-Cox, J.; Owen, J.S., Jr.; Oki, L.R.; White, S.A. Water use and treatment in container-grown specialty crop production: A review. Water Air Soil Pollut. 2017, 228, 151. [CrossRef] [PubMed]

3. Fulcher, A.F.; LeBude, A.V.; Owen Jr, J.S.; White, S.A.; Beeson, R.C. The next ten years: Strategic vision of water resources for nursery producers. HortTechnology 2016, 26, 121-132. [CrossRef]

4. Hong, C.; Richardson, P.A.; Kong, P. Pathogenicity to ornamental plants of some existing species and new taxa of Phytophthora from irrigation water. Plant Dis. 2008, 92, 1201-1207. [CrossRef] [PubMed]

5. Redekar, N.R.; Eberhart, J.L.; Parke, J.L. Diversity of Phytophthora, Pythium, and Phytopythium species in recycled irrigation water in a Container NURSERY. Phytobiomes J. 2019, 3, 31-45. [CrossRef]

6. $\quad$ Lea-Cox, J.D.; Zhao, C.; Ross, D.S.; Bilderback, T.E.; Harris, J.R.; Day, S.D.; Hong, C.; Yeager, T.H.; Richard, C.; Beeson, J.; et al. A nursery and greenhouse online knowledge center: Learning opportunities for sustainable practice. HortTechnology 2010, 20, 509-517. [CrossRef]

7. Mangiafico, S.S.; Gan, J.; Wu, L.; Lu, J.; Newman, J.P.; Faber, B.; Merhaut, D.J.; Evans, R. Detention and recycling basins for managing nutrient and pesticide runoff from nurseries. HortScience 2008, 43, 393-398. [CrossRef] 
8. Mangiafico, S.S.; Newman, J.P.; Mochizuki, M.J.; Zurawski, D. Adoption of sustainable practices to protect and conserve water resources in container nurseries with greenhouse facilities. Acta Hortic. 2008, 797, 367-372. [CrossRef]

9. Warsaw, A.L.; Thomas Fernandez, R.; Kort, D.R.; Cregg, B.M.; Rowe, B.; Vandervoort, C. Remediation of metalaxyl, trifluralin, and nitrate from nursery runoff using container-grown woody ornamentals and phytoremediation areas. Ecol. Eng. 2012, 47, 254-263. [CrossRef]

10. Baz, M.; Fernandez, R.T. Evaluating woody ornamentals for use in herbicide phytoremediation. J. Am. Soc. Hortic. Sci. 2002, 127, 991-997. [CrossRef]

11. Warner, L.A.; Lamm, A.J.; Beattie, P.; White, S.A.; Fisher, P.R. Identifying opportunities to promote water conservation practices among nursery and greenhouse growers. HortScience 2018, 53, 958-962. [CrossRef]

12. Hodges, A.W.; Hall, C.R.; Behe, B.K.; Dennis, J.H. Regional analysis of production practices and technology use in the U.S. nursery industry. HortScience 20018, 43, 1807-1812. [CrossRef]

13. Ingram, D.L.; Hall, C.R.; Knight, J. Carbon footprint and variable costs of production components for a container-grown evergreen shrub using life cycle assessment: An east coast U.S. Model. HortScience 2016, 51, 989-994. [CrossRef]

14. Ingram, D.L.; Hall, C.R.; Knight, J. Comparison of three production scenarios for Buxus microphylla var. japonica 'Green Beauty' Marketed in a No. 3 container on the west coast using life cycle assessment. HortScience 2017, 52, 357. [CrossRef]

15. Bilderback, T.E.; Boyer, C.; Chappell, M.R.; Fain, G.; Fare, D.; Gilliam, C.; Jackson, B.E.; Lea-Cox, J.; LeBude, A.V.; Owen, J.S.J.; et al. Best Management Practices: Guide for Producing Nursery Crops, 3rd ed.; Southern Nursery Association: Acworth, GA, USA, 2013.

16. Gundimeda, H.; Howe, C.W. Interstate river conflicts: Lessons from India and the US. Water Int. 2008, 33, 395-405. [CrossRef]

17. Holeton, C.; Chambers, P.A.; Grace, L.; Kidd, K. Wastewater release and its impacts on Canadian waters. Can. J. Fish. Aquat. Sci. 2011, 68, 1836-1859. [CrossRef]

18. Marshall, N.A.; Bailey, P.C.E. Impact of secondary salinisation on freshwater ecosystems: Effects of contrasting, experimental, short-term releases of saline wastewater on macroinvertebrates in a lowland stream. Mar. Freshw. Res. 2004, 55, 509-523. [CrossRef]

19. Pedrero, F.; Kalavrouziotis, I.; Alarcón, J.J.; Koukoulakis, P.; Asano, T. Use of treated municipal wastewater in irrigated agriculture-Review of some practices in Spain and Greece. Agric. Water Manag. 2010, 97, 1233-1241. [CrossRef]

20. Biel-Maeso, M.; Corada-Fernandez, C.; Lara-Martin, P.A. Monitoring the occurrence of pharmaceuticals in soils irrigated with reclaimed wastewater. Environ. Pollut. 2018, 235, 312-321. [CrossRef]

21. Crook, J.; Suampalli, R.Y. Water reclamation and resuse criteria in the U.S. Water Sci. Technol. 1996, 33, 451-462. [CrossRef]

22. Parsons, L.R.; Sheikh, B.; Holden, R.; York, D.W. Reclaimed water as an alternative water source for crop irrigation. HortScience 2010, 45, 1626-1629. [CrossRef]

23. Ferraro, N.; Bosch, D.; Pease, J.; Owen, J.S. Costs of capturing and recycling irrigation water in container nurseries. HortScience 2017, 52, 258. [CrossRef]

24. Pitton, B.J.L.; Hall, C.R.; Haver, D.L.; White, S.A.; Oki, L.R. A cost analysis for using recycled irrigation runoff water in container nursery production: A Southern California nursery case study. Irrig. Sci. 2018. [CrossRef]

25. United States Environmental Protection Agency. Overview of Identifying and Restoring Impaired Waters under Section 303(d) of the Clean Water Act. Available online: https:/www.epa.gov/tmdl/overviewidentifying-and-restoring-impaired-waters-under-section-303d-cwa (accessed on 26 September 2019).

26. Parrella, M.P.; Wagner, A.; Fujino, D.W. The floriculture and nursery industry's struggle with invasive species. Am. Entomol. 2015, 31, 39-50. [CrossRef]

27. Hall, T.J.; Dennis, J.H.; Lopez, R.G.; Marshall, M.I. Factors affecting growers' willingness to adopt sustainable floriculture practices. HortScience 2009, 44, 1346-1351. [CrossRef]

28. Yeager, T.H.; Merveldt, J.K.v.; Irani, T.A.; Larsen, C.A. Survey of reclaimed and non-reclaimed irrigation water use for production of container-grown platns in Florida. J. Environ. Hortic. 2015, 33, 119-124. [CrossRef] 
29. Christou, A.; Aguera, A.; Bayona, J.M.; Cytryn, E.; Fotopoulos, V.; Lambropoulou, D.; Manaia, C.M.; Michael, C.; Revitt, M.; Schroder, P.; et al. The potential implications of reclaimed wastewater reuse for irrigation on the agricultural environment: The knowns and unknowns of the fate of antibiotics and antibiotic resistant bacteria and resistance genes-A review. Water Res. 2017, 123, 448-467. [CrossRef]

30. Petousi, I.; Daskalakis, G.; Fountoulakis, M.S.; Lydakis, D.; Fletcher, L.; Stentiford, E.I.; Manios, T. Effects of treated wastewater irrigation on the establishment of young grapevines. Sci. Total Environ. 2019, 658, 485-492. [CrossRef]

31. Dery, J.L.; Rock, C.M.; Goldstein, R.R.; Onumajuru, C.; Brassill, N.; Zozaya, S.; Suri, M.R. Understanding grower perceptions and attitudes on the use of nontraditional water sources, including reclaimed or recycled water, in the semi-arid Southwest United States. Environ. Res. 2019, 170, 500-509. [CrossRef]

32. Michael, I.; Rizzo, L.; McArdell, C.S.; Manaia, C.M.; Merlin, C.; Schwartz, T.; Dagot, C.; Fatta-Kassinos, D. Urban wastewater treatment plants as hotspots for the release of antibiotics in the environment: A review. Water Res. 2013, 47, 957-995. [CrossRef]

33. Savchenko, O.M.; Kecinski, M.; Li, T.; Messer, K.D. Reclaimed water and food production: Cautionary tales from consumer research. Environ. Res. 2019, 170, 320-331. [CrossRef]

34. Rogers, E.M. Diffusion of Innovations, 4th ed.; Simon and Schuster: New York, NY, USA, 2010.

35. Lamm, A.J.; Warner, L.A.; Taylor, M.R.; Martin, E.T.; White, S.A.; Fisher, P.R. Diffusing water conservation and treatment technologies to nursery and greenhouse growers. J. Int. Agric. Ext. Educ. 2017, 24, 105-119. [CrossRef]

36. Otto, S.; Vianello, M.; Infantino, A.; Zanin, G.; Di Guardo, A. Effect of a full-grown vegetative filter strip on herbicide runoff: Maintaining of filter capacity over time. Chemosphere 2008, 71, 74-82. [CrossRef] [PubMed]

37. Krutz, L.J.; Senseman, S.A.; Zablotowicz, R.M.; Matocha, M.A. Reducing herbicide runoff from agricultural fields with vegetative filter strips: A review. Weed Sci. 2005, 53, 353-367. [CrossRef]

38. Harrell, L.J.; Ranjithan, S.R. Detention pond design and land use planning for watershed management. J. Water Res. Plan. Manag. 2003, 129, 98-106. [CrossRef]

39. White, S.A. Wetland technologies for nursery and greenhouse compliance with nutrient regulations. HortScience 2013, 48, 1103-1108. [CrossRef]

40. Taylor, M.D.; White, S.A.; Chandler, S.L.; Klaine, S.J.; Whitwell, T. Nutrient management of nursery runoff water using constructed wetland systems. HortTechnology 2006, 16, 610-614. [CrossRef]

41. Garcia Chance, L.M.; Van Brunt, S.C.; Majsztrik, J.C.; White, S.A. Short- and long-term dynamics of nutrient removal in floating treatment wetlands. Water Res. 2019, 159, 153-163. [CrossRef]

42. Spangler, J.T.; Sample, D.J.; Fox, L.J.; Owen, J.S.; White, S.A. Floating treatment wetland aided nutrient removal from agricultural runoff using two wetland species. Ecol. Eng. 2019, 127, 468-479. [CrossRef] 